Article

\title{
Effects of the Combination of $\beta$-Hydroxy- $\beta$-Methyl Butyrate and $R(+)$ Lipoic Acid in a Cellular Model of Sarcopenia
}

\author{
Lorenzo Di Cesare Mannelli ${ }^{1, *(\mathbb{D})}$, Laura Micheli ${ }^{1}$, Elena Lucarini ${ }^{1}{ }^{(}$, Carmen Parisio $^{1}{ }^{1}$, \\ Alessandra Toti ${ }^{1}$, Barbara Tenci ${ }^{1}$, Matteo Zanardelli ${ }^{1}$, Jacopo Junio Valerio Branca ${ }^{2}$ (D), \\ Alessandra Pacini ${ }^{2,+}$ and Carla Ghelardini ${ }^{1,+}$ \\ 1 Department of Neurosciences, Psychology, Drug Research and Child Health-Neurofarba-Pharmacology and \\ Toxicology Section, University of Florence. Viale Pieraccini 6, 50139 Florence, Italy; \\ laura.micheli@unifi.it (L.M.); elena.lucarini@unifi.it (E.L.); carmen.parisio@unifi.it (C.P.); \\ alessandra.toti@unifi.it (A.T.); barbara.tenci@unifi.it (B.T.); matteo.zanardelli@unifi.it (M.Z.); \\ carla.ghelardini@unifi.it (C.G.) \\ 2 Department of Experimental and Clinical Medicine, Anatomy Section, University of Florence, \\ Largo Brambilla 3, 50134 Florence, Italy; jacopojuniovalerio.branca@unifi.it (J.J.V.B.); \\ alessandra.pacini@unifi.it (A.P.) \\ * Correspondence: lorenzo.mannelli@unifi.it \\ + These authors contributed equally to this work.
}

Received: 5 March 2020; Accepted: 27 April 2020; Published: 30 April 2020

check for updates

\begin{abstract}
Sarcopenia is a clinical problem associated with several pathological and non-pathological conditions. The aim of the present research is the evaluation of the pharmacological profile of the leucine metabolite $\beta$-hydroxy- $\beta$-methyl butyrate $(\mathrm{HMB})$ associated with the natural $\mathrm{R}(+)$ stereoisomer of lipoic acid (R(+)LA) in a cellular model of muscle wasting. The $\mathrm{C} 2 \mathrm{C} 12$ cell line is used as myoblasts or is differentiated in myotubes, sarcopenia is induced by dexamethasone (DEX). A Bonferroni significant difference procedure is used for a post hoc comparison. DEX toxicity $(0.01-300 \mu \mathrm{M}$ concentration range) is evaluated in myoblasts to measure cell viability and caspase 3 activation after $24 \mathrm{~h}$ and $48 \mathrm{~h}$; cell incubation with $1 \mu \mathrm{M}$ DEX for $48 \mathrm{~h}$ is chosen as optimal treatment for decreasing cell viability and increasing caspase 3 activity. $\mathrm{R}(+)$ LA or HMB significantly prevents DEX-induced cell mortality; the efficacy is improved when $100 \mu \mathrm{M} \mathrm{R}(+) \mathrm{LA}$ is combined with $1 \mathrm{mM}$ $\mathrm{HMB}$. Regarding myoblasts, this combination significantly reduces DEX-evoked $\mathrm{O}_{2}^{-}$production and protein oxidative damage. During the early phase of myotube formation, the mixture preserves the number of myogenin-positive cells, whereas it completely prevents the DEX-dependent damage in a later phase of myotube differentiation (7 days), as evaluated by cell diameter and percentage of multinucleated cells. R(+)LA in association with HMB is suggested for sarcopenia therapy.
\end{abstract}

Keywords: thioctic acid; muscle wasting; myotube; oxidative stress; leucine

\section{Introduction}

Sarcopenia is characterized by loss of skeletal muscle mass combined with decreased skeletal muscle quality (skeletal muscle performance per unit skeletal muscle mass) [1]. Age and several catabolic conditions such as starvation, diabetes, sepsis, inactivity and drugs (like glucocorticoids and chemotherapeutics) favor its development and strongly reduce quality of life, causing frailty [2]. Sarcopenia is considered a predictor of future mortality in middle-aged as well as older adults [3,4].

The mechanisms underlying the development of sarcopenia are multi-factorial and include the increase of protein breakdown [5,6], oxidative stress [7-10] and nervous alterations [11]. Protein 
degradation in skeletal muscle can be promoted by three different pathways: the ubiquitin-proteasomal pathway, the autophagic-lysosomal pathway and the calpain pathway. The ubiquitin-proteasomal pathway mediates the turnover of the majority of muscular protein; it is associated with the expression of the forkhead box $\mathrm{O}$ (FoxO) transcription factor that promotes the expression of muscle specific ubiquitin ligases such as atrophy gene-1/muscle atrophy F-box and muscle ring-finger protein 1 (MuRF1) [12,13], which mediate bond formation between protein and ubiquitin molecules [14]. The up-regulation of this pathway leads to muscle atrophy $[15,16]$ and can be associated with the activation of apoptotic signals. The activation of caspase- 3 in catabolic states yields a significant increase in protein degradation by the ubiquitin-proteasome system [17]. Indeed, caspase- 3 and -8 inhibitors reduce the auto-phosphorylation of double-stranded RNA-dependent protein kinase whose activation induces an increase in protein breakdown in response to pro-inflammatory cytokines (such as TNF- $\alpha$ ) and reactive oxygen species (ROS) production [18]. Circularly, sarcopenia favors oxidative stress. Regarding the case of muscle mass reduction, the function of the antioxidant enzymes catalase and glutathione peroxidase decline $[9,10]$, and mitochondrial activity is altered resulting in an overproduction of free radicals $[19,20]$. ROS may trigger apoptosis [21].

Despite the knowledge of muscle mass regulation mechanisms gained lately, effective treatments for sarcopenia are lacking. Recently, nutrient supplementation with the branched-chain amino acid leucine and its metabolite $\beta$-hydroxy- $\beta$-methyl butyrate (HMB) emerged [22] as able to improve protein balance and reduce muscle wasting in cancer [23], acquired immunodeficiency syndrome (AIDS) [24], and aging [25]. This effect can be associated to HMB's ability to attenuate the depression of protein synthesis induced by both a proteolysis-inducing factor and angiotensin II [26], and the induction of protein degradation in murine myotubes induced by a proteolysis-inducing factor [27]. Moreover, HMB has been shown to modulate the ubiquitin-proteasome system acting on the mammalian target of the rapamycin (mTOR) pathway [28,29] and to inhibit apoptosis induced by double-stranded RNA-dependent protein kinase [18]. Aiming to plan a potentially active synergistic association against sarcopenia, we conceive and test the association of HMB with the naturally occurring antioxidant compound lipoic acid (LA). LA is able to reduce mitochondrial dysfunction by acting as a cofactor in mitochondrial dehydrogenase complexes and, consequently, hinder ROS formation [30-32]. LA is widely employed as an adjuvant treatment of neuropathic pain and its ability to attenuate muscle damage/wasting has emerged as well $[33,34]$. LA has two optical isomers designated as $R(+)$ and $\mathrm{S}(-)$. The natural enantiomer $\mathrm{R}(+) \mathrm{LA}$ has been recently described as the eutomer, at least regarding antioxidant effects as well as neurovascular protection and pain relief $[21,35]$. The lysine salt of $R(+) L A$ is quite stable and, therefore, useful in therapeutic applications.

The protective effects of HMB and $\mathrm{R}(+) \mathrm{LA}$, alone or in mixture, are evaluated in an in vitro model of DEX-induced sarcopenia, a model widely used by several research groups, both in vitro and in vivo, to study the mechanisms that cause sarcopenia [36-39]. Furthermore, weight loss, muscle wasting, and cachexia in patients are well-known side effects of glucocorticoid treatment, thus, the discovery of drugs to protect against protein degradation is an important research goal to investigate further $[40,41]$.

\section{Materials and Methods}

\subsection{Cell Cultures}

C2C12 mouse skeletal myoblasts were obtained from American Type Culture Collection (Manassas, VA, USA), grown in Dulbecco's Modified Eagle Medium (DMEM) (Euroclone, Milan, Italy) supplemented with 10\% fetal bovine serum (FBS) (Euroclone, Milan, Italy), $100 \mathrm{U} / \mathrm{mL}$ penicillin and $100 \mu \mathrm{g} / \mathrm{mL}$ streptomycin, $200 \mathrm{mM}$ L-glutamine (Life Technologies Italia, Milan, Italy) and maintained at $37{ }^{\circ} \mathrm{C}$ in a humidified atmosphere of $5 \% \mathrm{CO}_{2}$. To induce myoblast differentiation into myotubes, C2C12 were cultured until reaching $80 \%$ of confluency, after which cells were shifted to a differentiation medium (DM: DMEM supplemented with $2 \%$ horse serum) for $72 \mathrm{~h}$ and for 7 days). 


\subsection{Pharmacological Treatments}

Upon reaching confluence, myoblasts were plated in appropriate cell culture plates (Corning Costar, Milan, Italy) and treated with dexamethasone (DEX) (Merck, Milan, Italy) at different concentrations for 24 or $48 \mathrm{~h}$. Lysine thioctate $(\mathrm{R}(+)$ lipoic acid-R(+)LA) and calcium $\beta$-hydroxy- $\beta$-methylbutyrate (HMB) (Barentz, Milan, Italy) were used either alone or in combination, in the presence or absence of DEX.

\subsection{Cell Viability Assay}

Myoblast cell viability was evaluated by the reduction of 3-(4,5-dimethylthiozol-2-yl)-2,5diphenyltetrazolium bromide (MTT) (Merck, Milan, Italy) as an index of mitochondrial functionality. Cells were plated into 96-well cell culture plates $\left(3 \times 10^{3}\right.$ cells/well). After $48 \mathrm{~h}$, cells were treated with $\operatorname{DEX}(0.01,0.03,0.1,1,3,10,30,100,300 \mu \mathrm{M})$ for an additional 24 or $48 \mathrm{~h}$. Myoblasts also were incubated with $\mathrm{R}(+) \mathrm{LA}(1,10,30,100,300 \mu \mathrm{M})$ and $\operatorname{HMB}(1,10,30,100,300,1000,3000 \mu \mathrm{M})$ either alone or in combination, in the presence or absence of DEX $(0.01,0.03,0.1,1,10 \mu \mathrm{M})$ for $48 \mathrm{~h}$. All treatments were done in serum-free DMEM. After extensive washing, $1 \mathrm{mg} / \mathrm{mL}$ MTT was added into each well and incubated for $30 \mathrm{~min}$ at $37^{\circ} \mathrm{C}$. Then, the formazan crystals were dissolved in $150 \mathrm{~mL}$ dimethyl sulfoxide. The absorbance was measured at $550 \mathrm{~nm}$. Experiments were performed in quadruplicate on at least three different cell batches.

\subsection{Caspase-3 Activity}

C2C12 myoblasts were plated into 6-well plates $\left(5 \times 10^{4}\right.$ cells/well $)$ and grown until confluent. Incubation, with increasing concentrations of DEX $(0.01-100 \mu \mathrm{M})$ and four different mixtures of $\mathrm{R}(+) \mathrm{LA}$ and HMB $(30 \mu \mathrm{M}$ and $100 \mu \mathrm{M}, 30 \mu \mathrm{M}$ and $300 \mu \mathrm{M}, 100 \mu \mathrm{M}$ and $300 \mu \mathrm{M}, 100 \mu \mathrm{M}$ and $1000 \mu \mathrm{M}$, respectively), was allowed for $48 \mathrm{~h}$. Concurrently, $1 \mu \mathrm{M}$ DEX was incubated with increasing concentrations of $\mathrm{R}(+) \mathrm{LA}(1,10,30,100,300 \mu \mathrm{M})$ and $\mathrm{HMB}(30,100,300,1000,3000 \mu \mathrm{M})$, either alone or in combination, for $48 \mathrm{~h}$. After treatment, cells were scraped into $100 \mu \mathrm{L}$ of lysis buffer (200 mM tris-hydrogen chloride (Tris- $\mathrm{HCl}$ ) buffer, $\mathrm{pH} 7.5$, containing $2 \mathrm{M} \mathrm{NaCl}, 20 \mathrm{mM}$ ethylenediaminetetraacetic acid (EDTA), and $0.2 \%$ Triton X-100) (Merck, Milan, Italy). Fifty microlitres of the supernatant was incubated with $25 \mu \mathrm{M}$ of the fluorogenic peptide caspase substrate, rhodamine 110 bis (N-CBZ-L-aspartyl-L-glutamyl-L-valyl-L-aspartic acid amide) (Molecular Probes, Milan, Italy), at $25{ }^{\circ} \mathrm{C}$ for $30 \mathrm{~min}$. The amount of cleaved substrate was measured in a 96-well plate fluorescence spectrometer (FlexStation 3, Molecular Devices; excitation at $496 \mathrm{~nm}$ and emission at $520 \mathrm{~nm}$ ).

\subsection{Superoxide Dismutase-Inhibitable Superoxide Anion $\left(\mathrm{O}_{2}^{-}\right)$Production Evaluated by Cytochrome C Assay}

$\mathrm{C} 2 \mathrm{C} 12$ myoblasts were plated in six-well plates $\left(5 \times 10^{4}\right.$ cells/well $)$ and grown until confluent. Cells were then incubated with increasing concentrations of $\operatorname{DEX}(0.01,0.03,0.1,0.3,1,10,100 \mu \mathrm{M})$ and with $1 \mu \mathrm{M}$ DEX in the presence or absence of $100 \mu \mathrm{M} \mathrm{R}(+) \mathrm{LA}, 1 \mathrm{mM} \mathrm{HMB}$ and the mixture $100 \mu \mathrm{M} \mathrm{R}(+) \mathrm{LA}-1$ $\mathrm{mM}$ HMB in serum-free DMEM containing cytochrome $\mathrm{C}(1 \mathrm{mg} / \mathrm{mL}$; Sigma-Aldrich, Milan, Italy) for $4 \mathrm{~h}$ at $37^{\circ} \mathrm{C}$. Nonspecific cytochrome $\mathrm{C}$ reduction was evaluated by carrying out tests in the presence of bovine superoxide dismutase (SOD; Sigma-Aldrich, Milan, Italy) $(300 \mathrm{mU} / \mathrm{m})$. The supernatants were collected and the optical density was measured at $550 \mathrm{~nm}$. After the nonspecific absorbance was subtracted, the SOD-inhibitable $\mathrm{O}_{2}{ }^{-}$amount was calculated using an extinction coefficient of $2.1 \times 10^{4} \mathrm{M}^{-1} \times \mathrm{cm}^{-1}$ and expressed as $\mu \mathrm{M} / \mathrm{mg}$ protein $/ 4 \mathrm{~h}$. The $4 \mathrm{~h}$ incubation interval was chosen on the basis of preliminary experiments which showed poor reliability for longer cytochrome $\mathrm{C}$ exposure to the cellular environment.

\subsection{Protein Extraction and Quantification}

C2C12 myoblasts were plated in a $25 \mathrm{~cm}^{2}$ cell culture flask $\left(10^{5}\right.$ cells/flask) and grown until confluent. To induce the differentiation, $\mathrm{C} 2 \mathrm{C} 12$ myotubes were plated in a $25 \mathrm{~cm}^{2}$ cell culture flask 
$\left(7 \times 10^{4}\right.$ cells/flask) and grown until $80 \%$ confluent. After that, cells were shifted to DM for 7 days. The DM was replaced every 2 days. Carbonylated proteins were evaluated after a $48 \mathrm{~h}$ incubation with $1 \mu \mathrm{M}$ DEX with or without $100 \mu \mathrm{M}$ R(+)LA, $1 \mathrm{mM} \mathrm{HMB}$ and the mixture $100 \mu \mathrm{M}$ R(+)LA-1 mM HMB. After incubation, myotube cell cultures were washed once with phosphate-buffered saline (PBS) (Euroclone, Milan, Italy) and scraped onto ice with a lysis buffer containing $50 \mathrm{mM}$ Tris- $\mathrm{HCl} \mathrm{pH}$ 8.0, $150 \mathrm{mM} \mathrm{NaCl}, 1 \mathrm{mM}$ EDTA, 0.5\% Triton X-100, and Complete Protease Inhibitor (Roche, Milan, Italy). Suspensions were then collected, subjected to a freeze-thaw cycle, and centrifuged at $13,000 \times g$ for $10 \mathrm{~min}$ at $4{ }^{\circ} \mathrm{C}$. Protein concentrations were quantified by a bicinchoninic acid assay.

\subsection{Carbonylated Protein Evaluation}

Protein carbonylation was evaluated both in $\mathrm{C} 2 \mathrm{C} 12$ myoblasts and $\mathrm{C} 2 \mathrm{C} 12$ differentiated myotubes. After extraction, $20 \mu \mathrm{g}$ samples of protein were denatured in $6 \%$ sodium dodecyl sulfate (Merck, Milan, Italy) and derivatized with $10 \mathrm{mM}$ 2,4-dinitrophenyl hydrazine (DNPH) (Merck, Milan, Italy) for $15 \mathrm{~min}$ at room temperature. Samples were separated on a $12 \%$ sodium dodecyl sulfate-polyacrylamide gel by electrophoresis (SDS-PAGE) and transferred onto nitrocellulose membranes (Bio-Rad, Milan, Italy). Membranes were blocked with $1 \%$ bovine serum albumin (BSA) (Merck, Milan, Italy) in PBS containing $0.1 \%$ Tween 20 (PBST) and then probed overnight with specific primary antibody versus DNPH (1:5000 in PBST/1\% BSA). After being washed with PBST, the membranes were incubated for $1 \mathrm{~h}$ in PBST containing the appropriate horseradish peroxidase-conjugated secondary anti-rabbit (1:5000; Cell Signaling, Danvers, MA, USA) and again washed. Enhanced chemiluminescence (ECL) (Pierce, Rockford, IL, USA) was used to visualize the peroxidase-coated bands. Densitometric analysis was performed using the Scion Image analysis software. Regarding each experiment, the density of all bands shown in a lane was reported as the mean. Glyceraldehyde-3-phosphate dehydrogenase (GAPDH) normalization was performed [42].

\subsection{Western Immunoblot Analysis}

$50 \mu \mathrm{g}$ of each sample were resolved with 10\% SDS-PAGE and transferred onto nitrocellulose membranes (Bio-Rad, Milan, Italy). Membranes were blocked with $5 \%$ nonfat dry milk in PBST and then probed overnight at $4{ }^{\circ} \mathrm{C}$ with primary antibody-specific versus muscle ring-finger protein-1 (MuRF1) (1:1000; 40 kDa; Santa Cruz, CA, USA), forkhead in rhabdomyosarcoma (FKHR) (1:1000; $80 \mathrm{kDa}$; Santa Cruz, CA, USA) or GAPDH (1:5000; $37 \mathrm{kDa}$; Santa Cruz, CA, USA). Membranes were then incubated for $1 \mathrm{~h}$ in PBST containing the appropriate horseradish peroxidase-conjugated secondary anti-rabbit (1:5000; Cell Signaling), anti-goat (1:5000; Merck, Milan, Italy) or anti-mouse antibody (1:2000; Santa Cruz, CA, USA). ECL was used to visualize the peroxidase-coated bands. Densitometric analysis was performed using the "ImageJ" analysis software (ImageJ, NIH, Bethesda, MD, USA) and results were normalized to $\alpha$-Tubulin immunoreactivity as an internal control. Values were reported as percentages in comparison to the control, which was arbitrarily fixed at $100 \%$.

\subsection{Immunofluorescence}

C2C12 myoblasts were plated into coverslips $\left(5 \times 10^{3}\right.$ cells/slice) and grown until confluent. After that, cells were exposed to DM for $24 \mathrm{~h}$ and, subsequently, subjected to pharmacological treatment for $48 \mathrm{~h}$ in DM. Cells were treated with $1 \mu \mathrm{M}$ DEX in the presence or absence of $100 \mu \mathrm{M} \mathrm{R}(+) \mathrm{LA}, 1 \mathrm{mM} \mathrm{HMB}$ or the mixture of both $100 \mu \mathrm{M} R(+) \mathrm{LA}-1 \mathrm{mM} \mathrm{HMB}$ and then fixed in $4 \%$ buffered paraformaldehyde for $10 \mathrm{~min}$ at room temperature. Fixed cells were permeabilized with PBS containing $0.1 \%$ Triton X-100 for $10 \mathrm{~min}$ and then incubated with a blocking solution containing $0.5 \% \mathrm{BSA}$ and $3 \%$ glycerol in PBS for $30 \mathrm{~min}$. After blocking, cells were incubated at $4{ }^{\circ} \mathrm{C}$ overnight with mouse monoclonal anti-myogenin (1:50; Santa Cruz, CA, USA). To reveal the immunostaining, the cells were incubated with goat anti-mouse Alexa Fluor 568-conjugated IgG (1:200; Life Technologies, Italy) for $1 \mathrm{~h}$ at room temperature. Negative controls were carried out by replacing the primary antibody with non-immune mouse serum; cross-reactivity of the secondary antibody was tested in control experiments in which 
the primary antibody was omitted. During some experiments, counterstaining was performed with either TRITC-labeled phalloidin (1:40; Life Technologies, Italy) to reveal filamentous actin and 4',6-diamidine-2' -phenylindole dihydrochloride (DAPI) (1:2000; Merck, Milan, Italy) to reveal nuclei. After washing, the coverslips containing the immunolabeled cells were mounted with the mounting medium ProLong (Life Technologies, Milan, Italy) and observed under a motorized Leica DM6000B microscope equipped with a DFC350FX camera (Leica, Mannheim, Germany). Quantitative analysis of myogenin-positive cells was performed by collecting at least three independent fields through a 20X 0.5NA objective. Myogenin-positive cells were counted in $72 \mathrm{~h}$ differentiated myotubes using the "cell counter" plugin of ImageJ. The myogenin signal in immunostained sections was quantified using FIJI software (distributed by ImageJ, NIH, Bethesda, MD, USA) by automatic thresholding images with the aid of the "Moments" algorithm, which we found to provide the most consistent pattern recognition across all acquired images. Results were expressed as a percentage calculated by the ratio between the number of myogenin-positive cells and the total cells identified by DAPI (100\%).

\subsection{Morphologic Evaluations}

C2C12 myotubes were plated on coverslips $\left(5 \times 10^{3}\right.$ cells/slice $)$ and grown until confluent. After that, cells were shifted to DM for 7 days. The DM was replaced every 2 days. Pharmacological treatments were performed by incubating seven day-differentiated myotubes with $1 \mu \mathrm{M}$ DEX in the presence or absence of $100 \mu \mathrm{M} R(+) \mathrm{LA}, 1 \mathrm{mM} \mathrm{HMB}$, or the mixture of $100 \mu \mathrm{M} R(+) \mathrm{LA}-1 \mathrm{mM}$ HMB for $48 \mathrm{~h}$. After that, fixed cells were immunolabeled with either TRITC-labeled phalloidin (1:40; Life Technologies, Italy) to reveal filamentous actin or DAPI (1:2000) to reveal nuclei. The evaluation of myotube diameters, number of nuclei per myotube and multinucleated cells were done using image analyzing software (ImageJ 1.48). Morphometric analysis was performed by collecting at least three independent fields through a 20X 0.5NA objective, and micrographs to be analized were taken using a motorized Leica DM6000B microscope equipped with a DFC350FX camera (Leica, Mannheim, Germany).

\subsection{Statistical Analysis}

Results were expressed as mean \pm S.E.M. and analysis of variance (ANOVA) was performed. A Bonferroni significant difference procedure was used as a post hoc comparison. All assessments were made by researchers blinded to cell treatments. Data were analyzed using the "Origin 8.1" software (OriginLab, Northampton, MA, USA).

\subsection{Results}

\subsubsection{C2C12 Myoblasts}

Dexamethasone (DEX) decreased the viability of C2C12 myoblasts after $24 \mathrm{~h}$ incubation, taking effect starting from $0.1 \mu \mathrm{M}$ (Table 1 ). Reduction by about $30-40 \%$ was reached using $1 \mu \mathrm{M}$ DEX. The same concentration lowered cell viability by $50 \%$ at $48 \mathrm{~h}$. Higher concentrations did not increase the cell mortality rate (after both 24 and $48 \mathrm{~h}$ : Table 1). Choosing $1 \mu \mathrm{M}$ DEX for $48 \mathrm{~h}$ as standard damage, C2C12 myoblasts were treated with $\mathrm{R}(+)$ stereoisomer of lipoic acid $(\mathrm{R}(+) \mathrm{LA})$ and $\beta$-hydroxy- $\beta$-methyl butyrate (HMB) for testing protective properties. Shown in Figure 1, R(+)LA (100 and $300 \mu \mathrm{M})$ prevented DEX-induced cell damage, increasing viability from 50\% (DEX) to about $75 \%(300 \mu \mathrm{M}$ $\mathrm{R}(+) \mathrm{LA})$. HMB showed a significant effect starting from $1 \mathrm{mM}$, and a complete prevention of mortality was observed at $3 \mathrm{mM}$ (Figure 1). Considering concentrations of $100 \mu \mathrm{M}$ LA and $1 \mathrm{mM}$ HMB, full restoration of cellular viability was observed (Figure 1), suggesting synergism.

Effects of $\mathrm{R}(+) \mathrm{LA}$ and HMB on the viability of $\mathrm{C} 2 \mathrm{C} 12$ treated with DEX in the dose range $0.01-10 \mu \mathrm{M}$ for $48 \mathrm{~h}$ is shown in Table S1. 
Table 1. Viability of C2C12 myoblasts.

\begin{tabular}{ccc}
\hline & \multicolumn{2}{c}{ Cell Viability $\%$} \\
\hline $\begin{array}{c}\text { Dexamethasone } \\
\text { Concentration }(\mu \mathrm{M})\end{array}$ & $\mathbf{2 4} \mathbf{~}$ & $\mathbf{4}$ \\
\cline { 2 - 3 } & $100.0 \pm 0.9$ & $100 \pm 2.4$ \\
\hline 0 & $87.32 \pm 4.5$ & $69.1 \pm 1.8^{* *}$ \\
\hline 0.01 & $85.34 \pm 6.7$ & $62.4 \pm 4.6^{* *}$ \\
\hline 0.03 & $68.9 \pm 1.8^{* *}$ & $58.9 \pm 4.3^{* *}$ \\
\hline 0.1 & $65.4 \pm 1.7^{* *}$ & $47.6 \pm 3.3^{* *}$ \\
\hline 1 & $62.2 \pm 1.9^{* *}$ & $56.1 \pm 5.0^{* *}$ \\
\hline 3 & $63.3 \pm 1.8^{* *}$ & $52.3 \pm 2.3^{* *}$ \\
\hline 10 & $62.5 \pm 1.8^{* *}$ & $53.5 \pm 6.7^{* *}$ \\
\hline 30 & $61.3 \pm 0.4^{* *}$ & $52.4 \pm 3.8^{* *}$ \\
\hline 100 & $59.5 \pm 0.6^{* *}$ & $54.2 \pm 8.1^{* *}$ \\
\hline 300 & & \\
\hline
\end{tabular}

Cell viability of C2C12 myoblasts treated with increasing concentrations of DEX (0.01-300 $\mu \mathrm{M})$ for $24 \mathrm{~h}$ or $48 \mathrm{~h}$. The control condition was arbitrarily set as $100 \%$ and values are expressed as the mean \pm S.E.M. of 3 experiments. ** $p<0.01$ versus control $(0 \mu \mathrm{M})$.

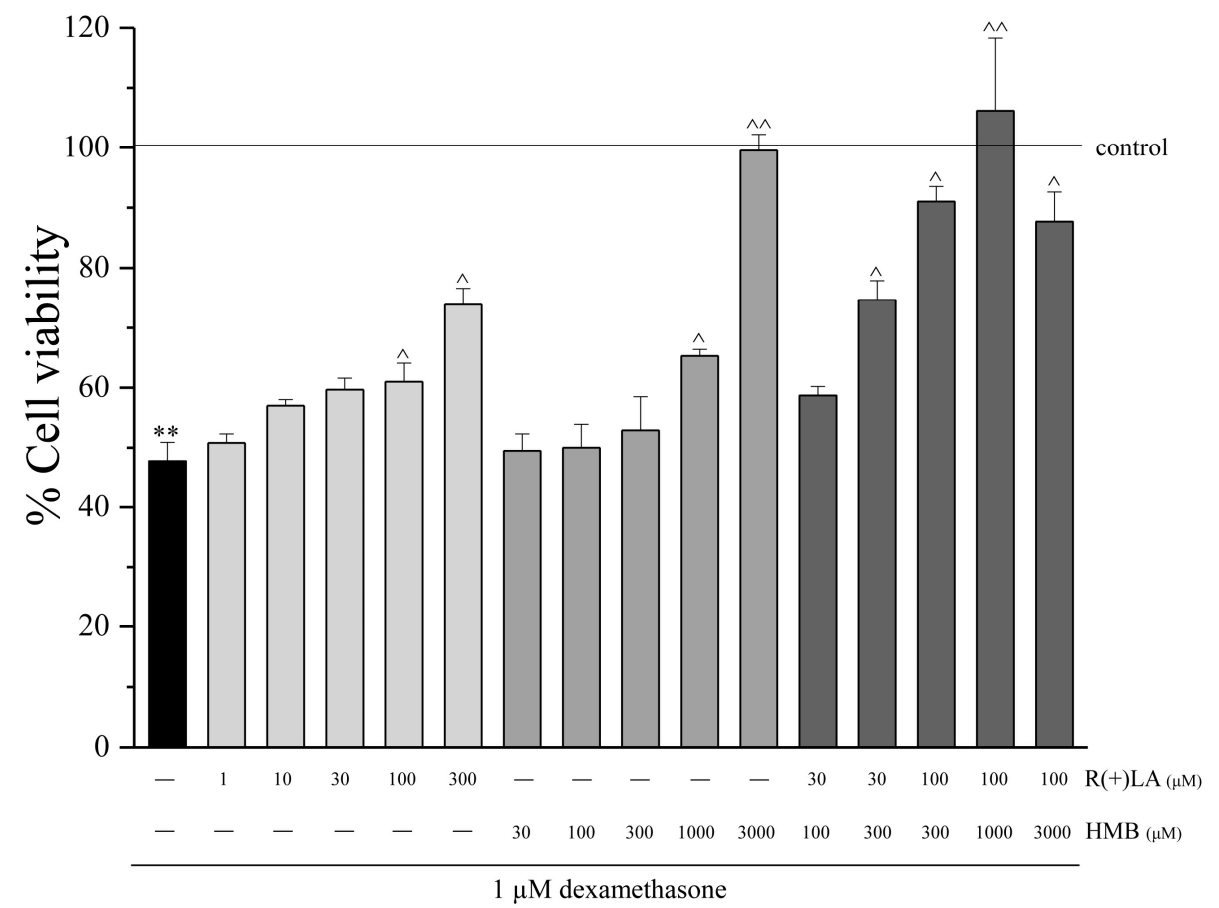

Figure 1. Viability of $\mathrm{C} 2 \mathrm{C} 12$ myoblasts. $\mathrm{C} 2 \mathrm{C} 12$ myoblasts were treated with $1 \mu \mathrm{M}$ DEX in the absence or presence of increasing concentrations of $\mathrm{R}(+) \mathrm{LA}(1-300 \mu \mathrm{M})$ or HMB $(30 \mu \mathrm{M}-3 \mathrm{mM})$, or the combination of both for $48 \mathrm{~h}$. Cell viability was measured by 3-(4,5-dimethylthiozol-2-yl)-2,5-diphenyltetrazolium bromide (MTT) assay. The control condition was arbitrarily set as $100 \%$ (black line) and values are expressed as the mean \pm S.E.M. of three experiments. ${ }^{* *} p<0.01$ versus control; ${ }^{\wedge} p<0.05$ and ${ }^{\wedge} p<0.01$ versus DEX treatment in the absence of $\mathrm{R}(+) \mathrm{LA}$ and $\mathrm{HMB}$.

During the absence of DEX, R(+)LA (1-300 $\mu \mathrm{M})$ and HMB $(1 \mu \mathrm{M}-1 \mathrm{mM})$ alone did not alter myoblast viability, whereas $3 \mathrm{mM}$ HMB and the mixture $\mathrm{R}(+) \mathrm{LA}+\mathrm{HMB}$ were able to increase $\mathrm{C} 2 \mathrm{C} 12$ viability. Particularly, $100 \mu \mathrm{M}$ R(+)LA/1 mM HMB enhanced viability by about $70 \%$ (Table S2). Shown in Table 2, DEX induced the apoptotic processes promoting caspase-3 activity. Characteristically, the 
enzymatic activity was increased by about $70 \%$ in the concentration range of corticosteroid $0.01-1 \mu \mathrm{M}$, while 10 and $100 \mu \mathrm{M}$ were no more able to induce caspase-3 activation (Table 2), suggesting that higher concentrations may overcome the apoptotic phenomena evoking toxicity signals that lead to cell mortality (shown also at these concentrations, Table 1) probably by necrotic mechanisms.

Table 2. Caspase-3 activity in C2C12 myoblast.

\begin{tabular}{|c|c|}
\hline Caspase-3 Activity \% & \\
\hline $\begin{array}{c}\text { Dexamethasone } \\
\text { Concentration }(\mu \mathrm{M})\end{array}$ & $48 \mathrm{~h}$ Incubation \\
\hline 0 & $100 \pm 3.4$ \\
\hline 0.01 & $160.6 \pm 20.1^{*}$ \\
\hline 0.1 & $171.7 \pm 14.9^{*}$ \\
\hline 0.3 & $170.3 \pm 16.8^{*}$ \\
\hline 1 & $177.3 \pm 15.2^{*}$ \\
\hline 10 & $106.2 \pm 4.4$ \\
\hline 100 & $94.5 \pm 5.9$ \\
\hline
\end{tabular}

Caspase-3 activity of C2C12 myoblasts treated with increasing concentrations of DEX $(0.01-100 \mu \mathrm{M})$ for $48 \mathrm{~h}$. The control condition was arbitrarily set as $100 \%$ and values are expressed as the mean \pm S.E.M. of three experiments. $* p<0.05$ versus control $(0 \mu \mathrm{M})$.

The pro-apoptotic activity induced by $1 \mu \mathrm{M}$ DEX ( $48 \mathrm{~h}$ ) was prevented by 1 and $3 \mathrm{mM} H \mathrm{HB}$ (Figure 2). A similar protective effect was induced by the mixture $100 \mu \mathrm{M} \mathrm{R}(+) \mathrm{LA} / 300 \mu \mathrm{M} \mathrm{HMB}$ (Figure 2).

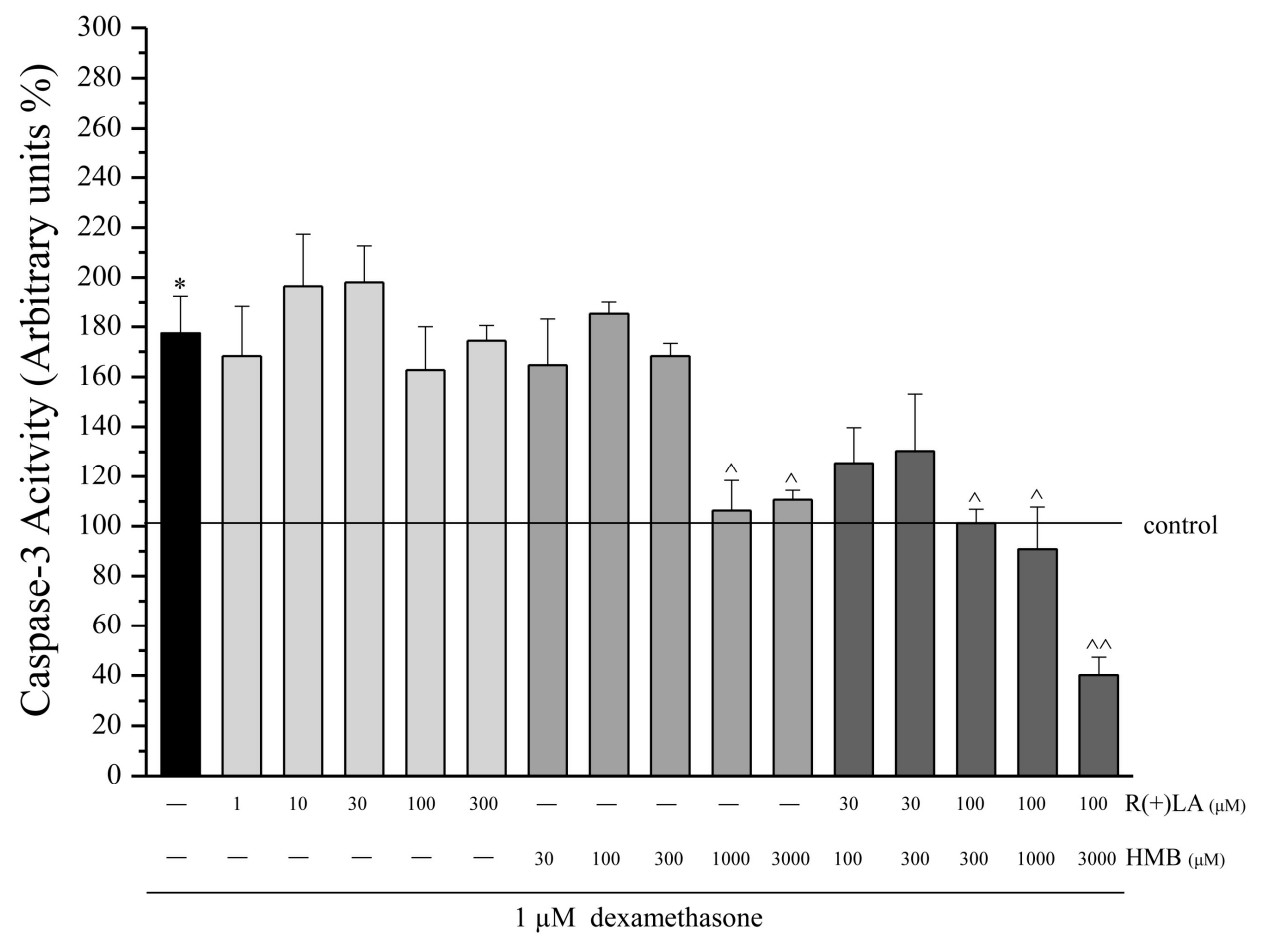

Figure 2. Caspase-3 activity percentage in $\mathrm{C} 2 \mathrm{C} 12$ myoblasts. $\mathrm{C} 2 \mathrm{C} 12$ myoblasts were treated with $1 \mu \mathrm{M}$ DEX in the absence or presence of increasing concentrations of $\mathrm{R}(+) \mathrm{LA}(1-300 \mu \mathrm{M})$ or HMB ( $30 \mu \mathrm{M}-3 \mathrm{mM})$, or the combination of both, for $48 \mathrm{~h}$. Caspase- 3 activity was measured by a fluorescence assay. The control condition was arbitrarily set as $100 \%$ (black line) and values are expressed as the mean \pm S.E.M. of 3 experiments. ${ }^{*} p<0.05$ versus control; ${ }^{\wedge} p<0.05,{ }^{\wedge} p<0.01$ versus DEX treatment in the absence of $\mathrm{R}(+) \mathrm{LA}$ and HMB. 
Regarding the absence of DEX, the basal activity of caspase-3 was not modified neither by R(+)LA nor by HMB (Table S3).

The treatment of $\mathrm{C} 2 \mathrm{C} 12$ myoblasts with DEX evoked an oxidative derangement. $\mathrm{O}_{2}{ }^{-}$levels increased concentration-dependence after $48 \mathrm{~h}$ of treatment (Table S4), inducing alterations of macromolecules like protein carbonylation (Figure 3B). The combination of R(+)LA $(100 \mu \mathrm{M})$ and HMB $(1 \mathrm{mM})$ was necessary to significantly prevent both $\mathrm{O}_{2}{ }^{-}$increase (Figure $3 \mathrm{~A}$ ) and protein carbonylation (Figure 3B) promoted by DEX $(1 \mu \mathrm{M}, 48 \mathrm{~h})$.
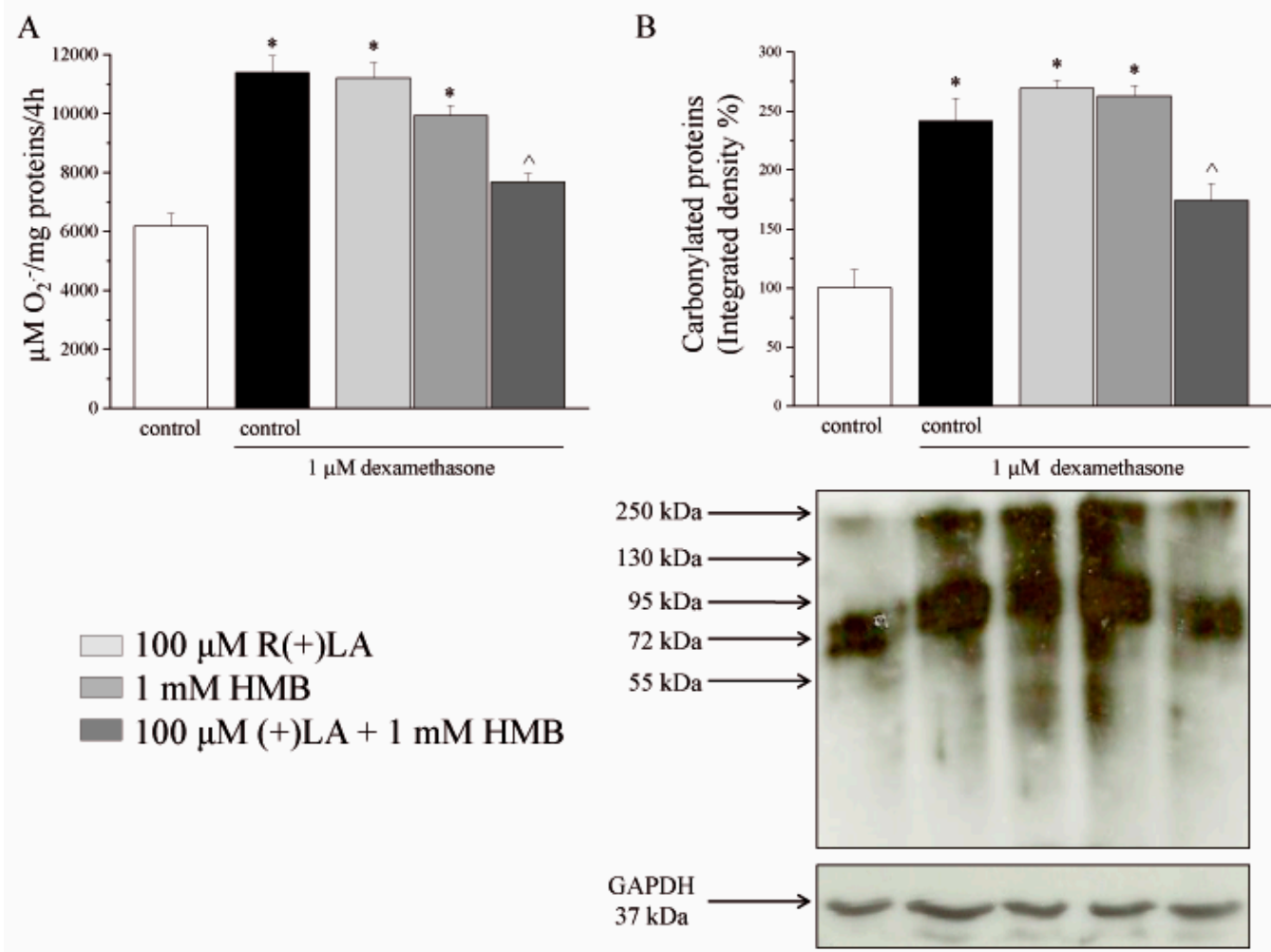

Figure 3. Oxidative stress in $\mathrm{C} 2 \mathrm{C} 12$ myoblasts. (A) $\mathrm{O}_{2}{ }^{-}$levels. $\mathrm{C} 2 \mathrm{C} 12$ myoblasts were exposed to $1 \mu \mathrm{M}$ DEX for $4 \mathrm{~h}$ in the absence or in the presence of $100 \mu \mathrm{M} \mathrm{R}(+) \mathrm{LA}$ or $1 \mathrm{mM} \mathrm{HMB}$ or the combination of both. $\mathrm{O}_{2}{ }^{-}$concentration was evaluated by cytochrome $\mathrm{C}$ assay. The non-specific absorbance was measured in the presence of superoxide dismutase (SOD) $(300 \mathrm{mU} / \mathrm{mL})$ and subtracted from the total value. Values are expressed as $\mu \mathrm{M} / \mathrm{mg}$ protein $/ 4 \mathrm{~h}$. Bars represent the mean \pm S.E.M. of 3 experiments. (B) Protein carbonylation. C2C12 myoblasts were treated for $48 \mathrm{~h}$ with $1 \mu \mathrm{M}$ DEX in the absence or presence of $100 \mu \mathrm{M} \mathrm{R}(+) \mathrm{LA}$ or $1 \mathrm{mM} \mathrm{HMB}$ or the combination of both. Western blot analysis was performed on cell homogenates using a specific antibody against DNPH. Densitometric analysis (top) and representative immunoblot (bottom) are shown. GAPDH normalization was performed for each sample. Values are expressed as the mean \pm S.E.M. percent of control performed in 3 different experiments. ${ }^{*} p<0.05$ versus control (in the absence of DEX) and ${ }^{\wedge} p<0.05$ versus DEX treatment in the absence of $\mathrm{R}(+) \mathrm{LA}$ and HMB.

\subsubsection{C2C12 Myotubes}

DEX $(1 \mu \mathrm{M}, 48 \mathrm{~h}$, added during the differentiation period between 24 and $72 \mathrm{~h})$ reduced the number of myogenin-positive cells by about $30 \%$. The co-treatment with $100 \mu \mathrm{M} \mathrm{R}(+) \mathrm{LA}$ or $1 \mathrm{mM}$ $\mathrm{HMB}$, alone or in mixture, restored myogenin expression (Figure 4). 

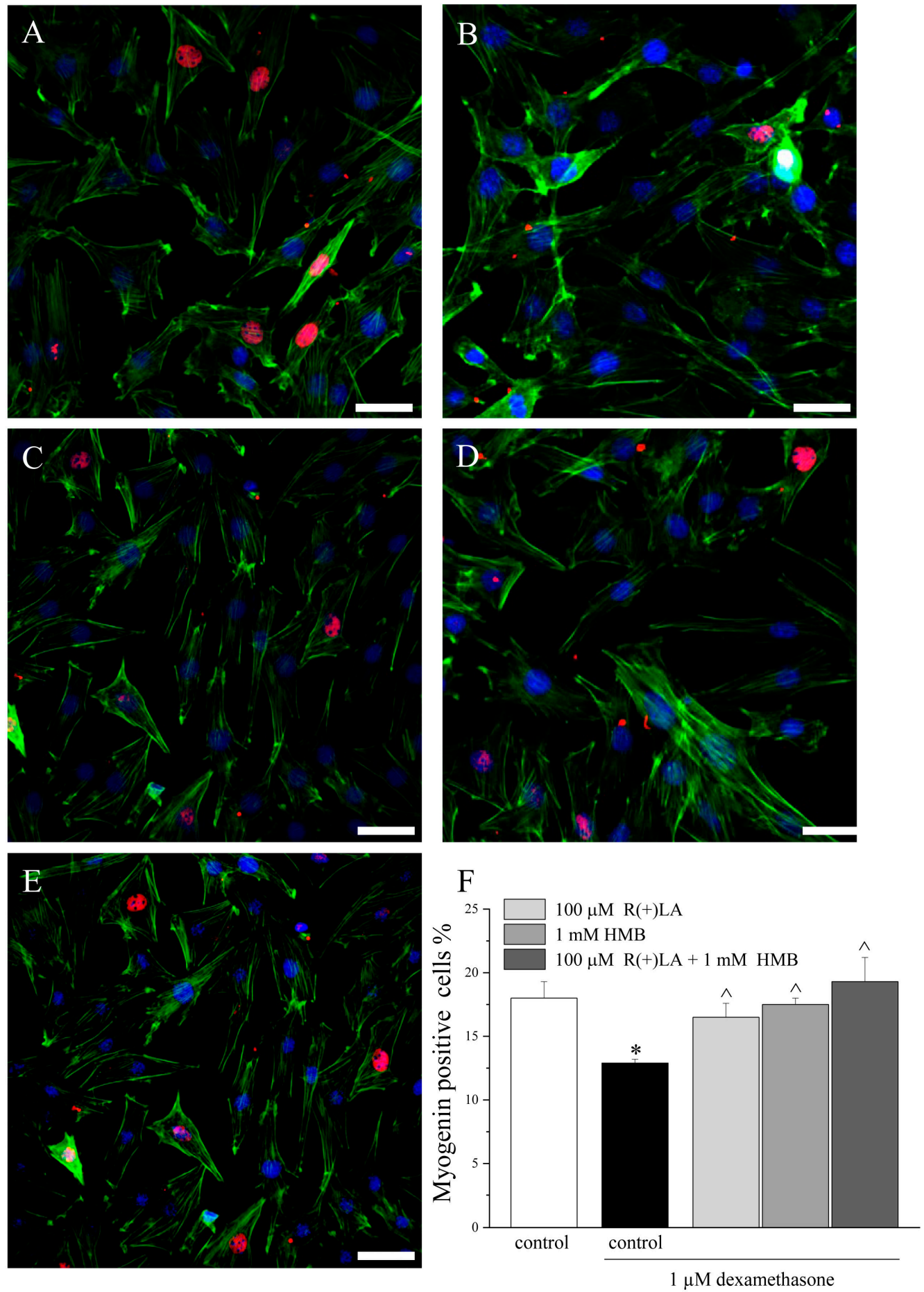

Figure 4. Myogenin staining of $\mathrm{C} 2 \mathrm{C} 12$ cells after $72 \mathrm{~h}$ differentiation. $\mathrm{C} 2 \mathrm{C} 12$ myoblasts were cultured for $24 \mathrm{~h}$ in differentiation medium (DM) and then incubated for $48 \mathrm{~h}$ as follows: with DM (A); with $1 \mu \mathrm{M}$ DEX (B); with $1 \mu \mathrm{M}$ DEX and $100 \mu \mathrm{M}$ R(+)LA (C); with $1 \mu \mathrm{M}$ DEX and $1 \mathrm{mM}$ HMB (D); with $1 \mu \mathrm{M}$ DEX, $100 \mu \mathrm{M}$ R(+)LA and $1 \mathrm{mM}$ HMB (E). The cells were then fixed and stained with Alexa488-conjugated phalloidin to evidence F-actin organization and a specific antibody that recognized myogenin (red). Nuclei were stained with 4',6-Diamidine-2' -phenylindole dihydrochloride (DAPI) (blue). (F) Quantitative analysis of the percentage of myogenin-positive cells. The percentage was calculated by the ratio between the number of myogenin-positive cells (red) and the total cells identified by DAPI $(100 \%)$. Scale bar (white line): $50 \mu \mathrm{m}$. Values are expressed as the mean \pm S.E.M. of 3 different experiments. ${ }^{*} p<0.05$ versus control (in the absence of DEX) and ${ }^{\wedge} p<0.05$ versus DEX treatment in the absence of $\mathrm{R}(+) \mathrm{LA}$ and HMB. 
The complete maturation of C2C12 myotubes was observed after 7 days of differentiation (F-actin staining, Figure 5) (cells showing two or more nuclei, as according to Lee [43]).

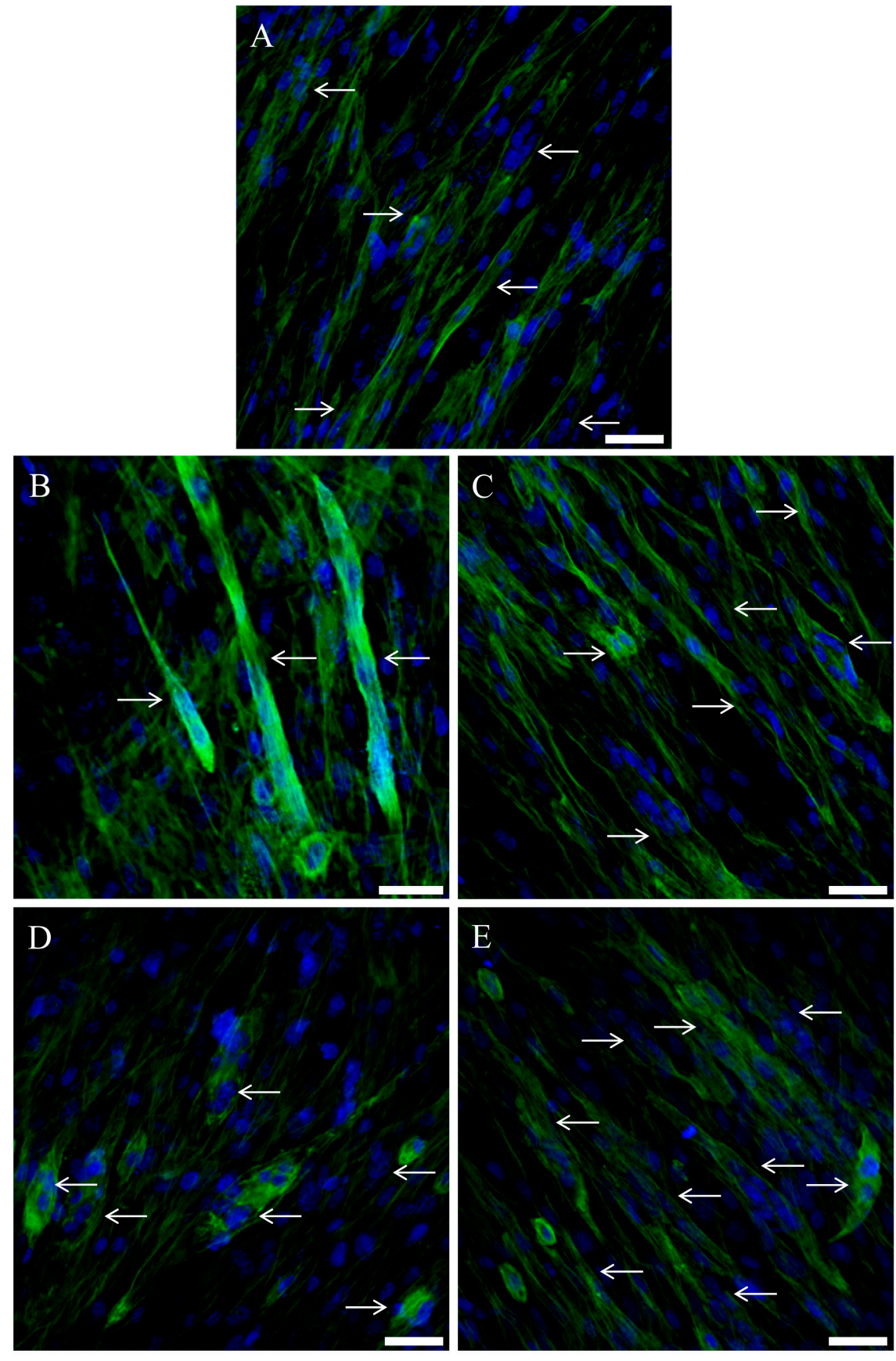

Figure 5. Morphological analysis of $\mathrm{C} 2 \mathrm{C} 12$ myotubes. C2C12 myoblasts were cultured in DM for 7 days. The cultures were then incubated for $48 \mathrm{~h}$ with DM (A); with $1 \mu \mathrm{M}$ DEX (B); with $1 \mu \mathrm{M}$ DEX and $100 \mu \mathrm{M}$ R(+)LA (C); with $1 \mu \mathrm{M}$ DEX and 1 mM HMB (D); with $1 \mu \mathrm{M}$ DEX, $100 \mu \mathrm{M} \mathrm{R}(+) \mathrm{LA}$ and $1 \mathrm{mM}$ HMB (E). Cells were then fixed and stained with Alexa488-conjugated phalloidin to evidence F-actin organization. Nuclei were stained with DAPI (blue). Scale bar (white line): $50 \mu \mathrm{m}$.

The subsequent treatment with $\operatorname{DEX}(1 \mu \mathrm{M}, 48 \mathrm{~h})$ altered the myotube morphology, reducing the myotube diameter (Figure 6A) and the number of multinucleated myotubes (Figure 6B) by about 36\% and $27 \%$, respectively. Concerning the presence of $100 \mu \mathrm{M} \mathrm{R}(+) \mathrm{LA}$ or $1 \mathrm{mM} \mathrm{HMB}$, alone or in mixture, morphological alterations were prevented (Figures 5 and 6). The number of nuclei per myotube was 
not modified by DEX or R(+)LA/HMB. Occurring on day 7 of differentiation, myogenin was no longer detectable (data not shown).
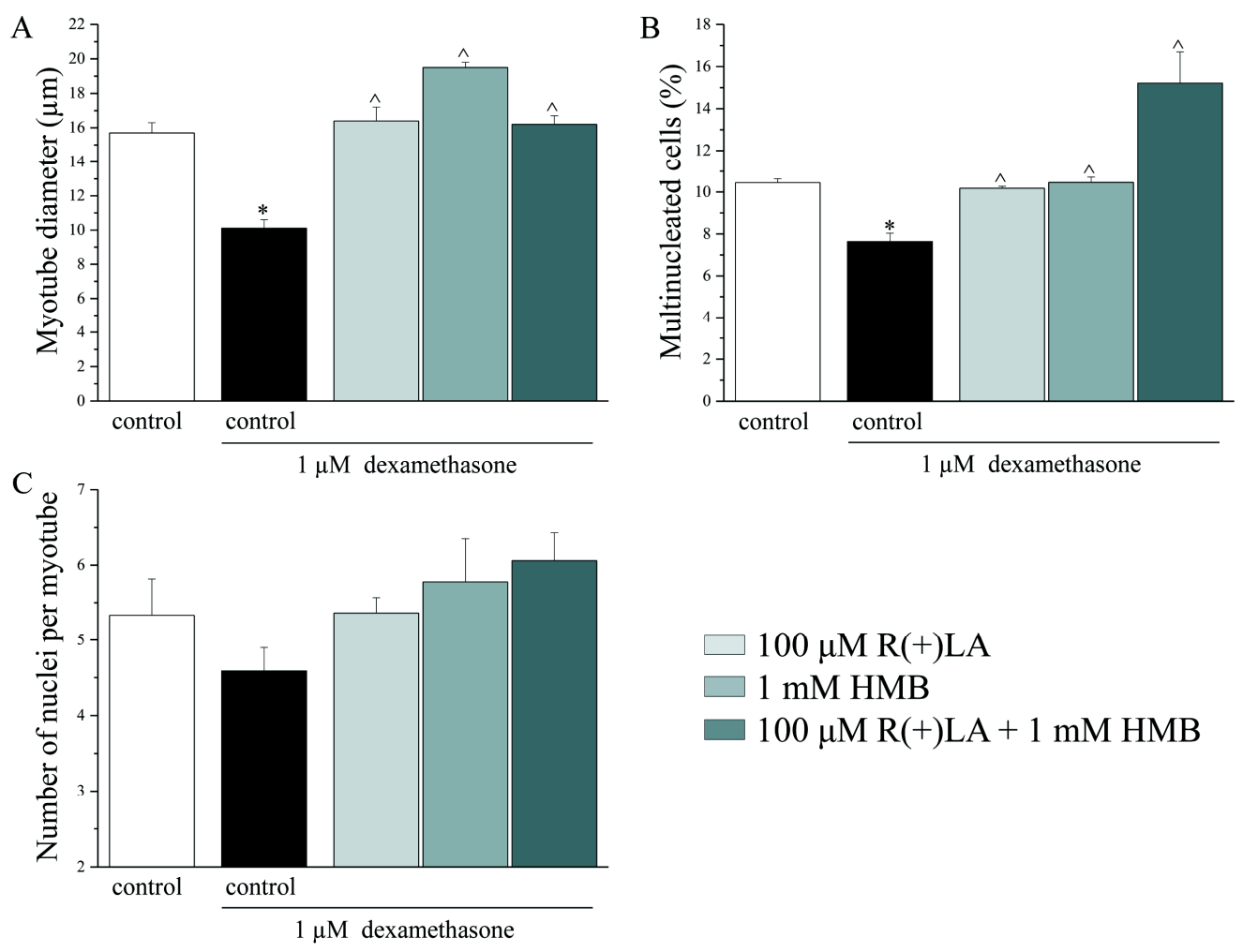

Figure 6. Morphometric analysis of $\mathrm{C} 2 \mathrm{C} 12$ myotubes. $\mathrm{C} 2 \mathrm{C} 12$ myoblasts were cultured in DM for 7 days. The cultures were then incubated for $48 \mathrm{~h}$ with $1 \mu \mathrm{M}$ DEX in the absence or presence of $100 \mu \mathrm{M}$ $\mathrm{R}(+) \mathrm{LA}$ or $1 \mathrm{mM} \mathrm{HMB}$, or the combination of both. After phalloidin staining, morphometric analyses were performed to provide: the measurement of the myotube diameter $(\mathbf{A})$, the multinucleated cell percentage (B) (determined as the ratio percent between the number of multinucleated cells and the number of total cells considered as $100 \%$ ), and the number of nuclei per myotube (C). The analyses were conducted in at least 3 random fields in each experimental group. Values are expressed as the mean \pm S.E.M. of three different experiments. ${ }^{*} p<0.05$ versus control (in the absence of DEX) and ${ }^{\wedge} p<0.05$ versus DEX treatment in the absence of $\mathrm{R}(+) \mathrm{LA}$ and HMB.

Shown in Figure 7, DEX also evoked oxidative damage in myotubes. Carbonylated protein expression was increased up to two fold (Figure 7A). Furthermore, muscle ring-finger protein 1 (MuRF1) and forkhead box O (FoxO) expression levels were increased up to three fold (Figure 7B,C). The mixture of $100 \mu \mathrm{M} R(+) \mathrm{LA} / 1 \mathrm{mM}$ HMB fully prevented protein oxidation, on the contrary, it did not modify the alterations induced by the corticosteroid on MuRF1 and FoxO (Figure 7).

\subsection{Discussion}

The described results show the synergistic effect of $R(+)$ stereoisomer of lipoic acid $(R(+) L A)$ and $\beta$-hydroxy- $\beta$-methyl butyrate (HMB) against the dexamethasone (DEX)-dependent damage of myoblast- and myotube-cell cultures. The optimal ratio between compounds has been defined.

Catabolic effects of glucocorticoids, including DEX, on muscle protein metabolism are well known. It is generally accepted that glucocorticoids are able to induce muscular atrophy, inhibiting muscle protein synthesis and stimulating muscle protein breakdown in both in vivo [44-47] and in vitro models [48-50]. The myotoxicity of DEX depends on cell type and is concentration-dependent with values between $10 \mathrm{nM}$ and $100 \mu \mathrm{M}[15,48,49,51,52]$. Our result of a threshold value of $1 \mu \mathrm{M}$ agrees with other reports regarding viability, caspase-3 activity and muscle ring-finger protein 1 
(MuRF1) and forkhead box O (FoxO) expression [50,53], both of which play a pivotal role in the ubiquitin-proteasome-dependent muscle atrophy induced by glucocorticoids [54].
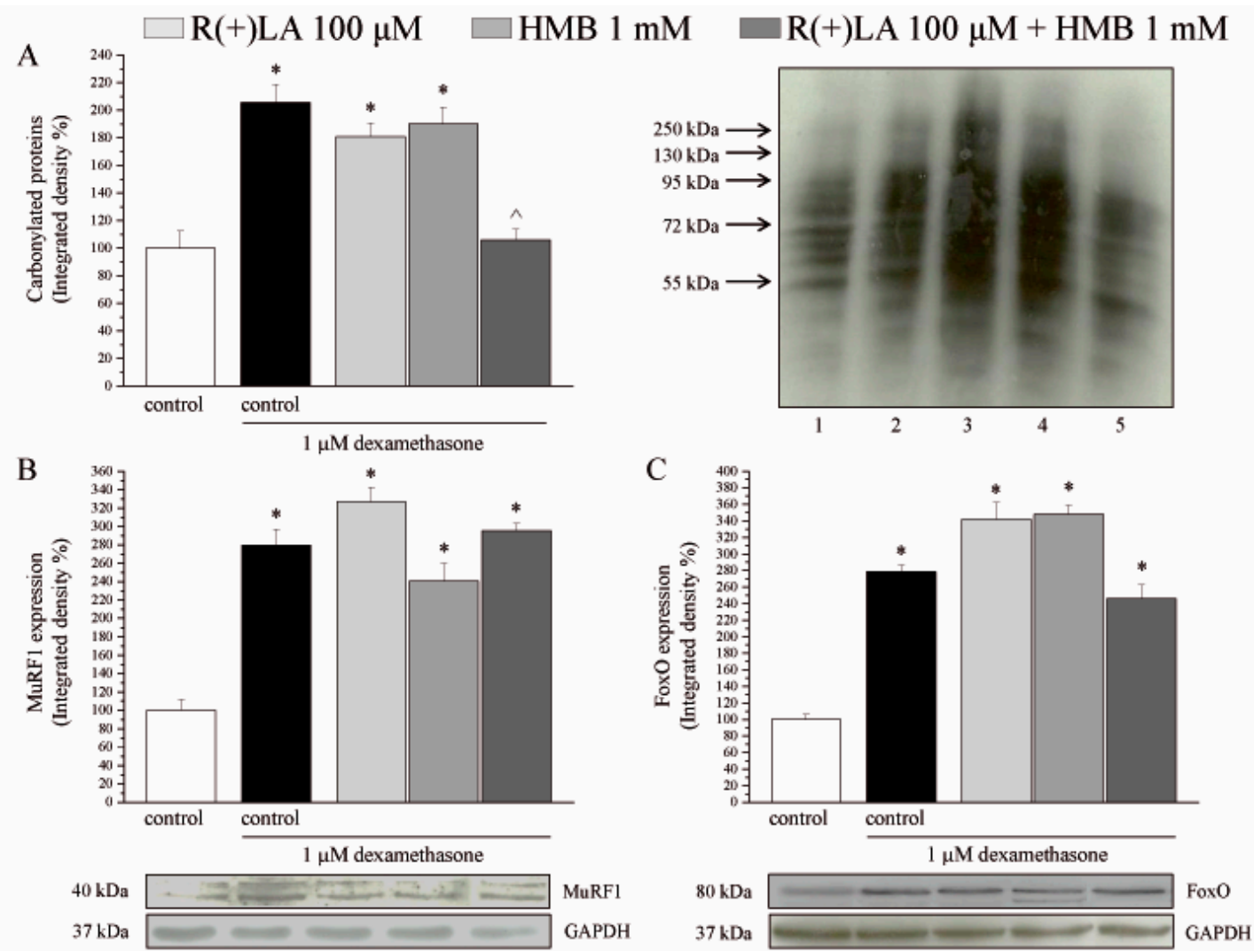

Figure 7. Protein expression levels of carbonylated proteins, MuRF1 and FoxO in C2C12 myotubes. Myotubes (7 day differentiation) were incubated for $48 \mathrm{~h}$ with $1 \mu \mathrm{M}$ DEX in the absence or presence of $100 \mu \mathrm{M} R(+) \mathrm{LA}$ or $1 \mathrm{mM} \mathrm{HMB}$, or the mixture of both. (A) Protein carbonylation. Densitometric analysis (left) and representative immunoblot (right) are shown. (B) MuRF1 protein expression levels. Densitometric analysis (top) and representative immunoblot (bottom) are shown. (C) FoxO expression levels in C2C12 myotubes. Densitometric analysis (top) and representative immunoblot (bottom) are shown. Alpha-Tubulin normalization was performed for each sample. Values are expressed as the mean \pm S.E.M. percent of control performed in 3 different experiments. ${ }^{*} p<0.05$ versus control (in the absence of DEX) and ^ $p<0.05$ versus DEX treatment in the absence of R(+)LA and HMB.

Found in this condition, both compounds $\mathrm{R}(+) \mathrm{LA}$ and HMB, were able, in a concentrationdependent manner, to protect $\mathrm{C} 2 \mathrm{C} 12$ muscle cells from DEX-induced damage; moreover, the combination promoted a synergistic effect regarding several parameters. Regarding myoblasts, the mixture $\mathrm{R}(+) \mathrm{LA} / \mathrm{HMB}(100 \mu \mathrm{M}$ and $1 \mathrm{mM}$, respectively) enhanced cell viability in the control condition as well, suggesting a proliferative effect without decreasing the basal caspase- 3 activity. Conversely, this effect on the basal condition agrees with the antioxidant potential of R(+)LA of reducing the oxidative stress produced by cell growth favoring proliferation, as well as by the nutrient supplementation due to HMB as a metabolite of the branched-chain amino acid leucine [22].

The mixture was more effective and powerful in comparison to single compounds in protecting from the toxicity induced by DEX, both as a mortality and apoptosis trigger. It is interesting to note that the combination $\mathrm{R}(+) \mathrm{LA} / \mathrm{HMB}$ was the only treatment able to significantly reduce the DEX-dependent redox imbalance by reducing the concentration of $\mathrm{O}_{2}{ }^{-}$and the level of carbonylated proteins, an oxidative modification due to the introduction of carbonyl groups into protein side chains by a site-specific mechanism [42] leading to decreased functionality. Furthermore, the protective effects of the combination $\mathrm{R}(+) \mathrm{LA} / \mathrm{HMB}$ also were highlighted in myotubes. During myotube differentiation 
from myoblast cultures, transcription factors of the myogenic differentiation gene family, including myogenin, play a pivotal role in the regulation of the fusion of myoblasts to form myotubes [55-57]. Agreeing with results from others $[13,58]$ we found that DEX decreased the expression of myogenin in $\mathrm{C} 2 \mathrm{C} 12$ myotubes. Furthermore, the diameter and the formation of mature myotubes were reduced. $\mathrm{R}(+) \mathrm{LA}$ and $\mathrm{HMB}$, alone and in combination, were able to counteract the decrease in myogenin-positive cell numbers induced by DEX, as well as to restore alterations in myotube diameters. Particularly, the co-treatment $\mathrm{R}(+) \mathrm{LA} / \mathrm{HMB}$ increased the number of multinucleated cells over the value of control cells. Again, the concomitant presence of both compounds was the only treatment able to significantly prevent the oxidative damage of myotube proteins.

Glucocorticoids lead to mitochondrial dysfunction and this has been linked to excessive reactive oxygen species (ROS) production $[59,60]$. Among other effects, both compounds R(+)LA and HMB possess antioxidant activities which involve the reduction of ROS by scavenging properties or by restoring the glutathione redox state due to the elevation of intracellular cysteine levels [61]. These mechanisms are related to the attenuation of muscle wasting $[62,63] . \mathrm{R}(+) \mathrm{LA}$ is the centerpiece of the pyruvate dehydrogenase complex, which functionally links glycolysis in the cytoplasm to oxidative phosphorylation in the mitochondria; its antioxidant properties are largely reported [61,64]. Lipoic acid (LA) can actively counter various forms of oxidative stress; it prevents the damage caused by oxygen free radicals thanks to its ability to cross cell membranes very quickly, and to act as an antioxidant in both lipid and aqueous phases [65-67]. LA biological activity is particularly referable to the natural $\mathrm{R}$ dextrorotatory enantiomer [21,35]. Only R(+)LA is synthesized by cells and works as a cofactor for some critical mitochondrial enzymes: pyruvate dehydrogenase, branched-chain $\alpha$-keto-acid dehydrogenase, and $\alpha$-ketoglutarate dehydrogenase [68]. Recently, other peculiar effects of LA against muscle wasting have emerged. LA was effective against diabetic myopathy by reducing morphological alterations in slow and fast rat skeletal muscles [69] and preserved muscle mass in diabetic rats by upregulating the AMPK/SIRT1/PGC- $1 \alpha$ (5'AMP-activated protein kinase/ Sirtuin $1 /$ peroxisome proliferator-activated receptor $\gamma$ coactivator $1 \alpha$ ) and AKT/mTOR/p70S6K (protein kinase $\mathrm{B} /$ mammalian target of rapamycin/ p70S6 kinase) signaling pathways [34]. Particularly, the role of PGC- $1 \alpha$ in LA-mediated muscle protection was recently confirmed in a rat model of DEX-dependent sarcopenia [70].

Regarding $\mathrm{HMB}$, it is metabolized in the cytosol joining a coenzyme A molecule, the resulting compound is converted in $\beta$-hydroxy- $\beta$-methylglutaryl coenzyme A (HMG-CoA), the primary metabolite of HMB in the body. HMG-CoA is then reducted into mevalonic acid, one of the precursors for the synthesis of cholesterol, which is involved in the integrity of the myocyte cell membrane [71].

Moreover, HMB showed direct antioxidant effects. Regarding murine myotubes, HMB reduced ROS formation induced by lipopolysaccharides [72]; concerning humans, it improves the dynamics of mitochondria, an intracellular organelle strongly affected by sarcopenia-like conditions which induce energy stress and elevated ROS production [73]. Conversely, HMB presents a multifactorial pharmacodynamic mechanism of action justifying its efficacy in muscle cell protection and muscular performance enhancement. As a metabolite of the branched-chain amino acid leucine, several studies recently reported that HMB supplementation represents a strategy for increasing power and muscle hypertrophy in healthy, trained subjects [74]. HMB reduces protein breakdown acting on the mTOR pathway and by inhibiting the ubiquitin-proteasome proteolytic pathway $[28,29,75]$, further, it stimulates protein synthesis as well as myogenic differentiation and survival via the PI3K (phosphoinositide 3-kinase)/AKT pathway [76]. To note, these positive profiles appear to be strongly related to the use of a correct dosage [75], since low dosage resulted in no effective treatments [77]. To summarise, the beneficial effects of LA and HMB in counteracting DEX-induced myotoxicity are due to their antioxidant property, their activation of the mTOR cascade, and their inhibition of the proteasome pathway. 


\subsection{Conclusions}

These results highlight the protective effects of $\mathrm{R}(+) \mathrm{LA}$ combined with HMB in myoblastand myotube-cultures damaged by DEX. In vivo preclinical studies are necessary for the clinical employment of the combination, based on the extensive use of both individual compounds in humans and their good safety profile. These data offer a rationale to candidate the mixture as a therapeutic option for sarcopenia treatment.

Supplementary Materials: The following are available online at http:/www.mdpi.com/1420-3049/25/9/2117/s1, Table S1: Viability of C2C12 myoblasts, Table S2: Viability of C2C12 myoblasts, Table S3: Caspase-3 activity in C2C12 myoblasts, Table S4: Superoxide anion levels in C2C12 myoblasts

Author Contributions: L.D.C.M. planned experiments, revised the work, wrote the paper, L.M. performed experiments and contributed to wrote the paper and to design figures, E.L. performed experiments and designed figures, C.P. performed experiments and contributed to design figures, A.T. wrote the paper and contributed with essential paper revision, B.T. performed experiments and contributed to wrote the paper and to design figures, M.Z. performed experiments J.J.V.B. designed figures, A.P. and C.G. planned experiments, revised the work, wrote the paper. All authors contributed to the final manuscript. All authors have read and agreed to the published version of the manuscript

Funding: This research was funded by the Italian Ministery of University and Research and from the University of Florence.

Conflicts of Interest: The authors declare no conflict of interest.

\section{Abbreviations}

HMB

$\mathrm{R}(+) \mathrm{LA}$

DEX

FoxO

MuRF1

ROS

MTOR

LA

DMEM

FBS

DM

MTT

$\mathrm{HCl}$

EDTA

SOD

PBS

DNPH

SDS-PAGE

BSA

PBST

GAPDH

FKHR

ECL

DAPI

AMPK

SIRT1

PGC- $1 \alpha$

AKT

p70S6K

HMG-CoA

PI3K
$\beta$-Hydroxy- $\beta$-methyl butyrate

$\mathrm{R}(+)$ stereoisomer of lipoic acid

dexamethasone

forkhead box $\mathrm{O}$

muscle ring-finger protein 1

reactive oxygen species

mammalian target of rapamycin

lipoic acid

Dulbecco's Modified Eagle Medium

fetal bovine serum

differentiation medium

3-(4,5-dimethylthiozol-2-yl)-2,5-diphenyltetrazolium bromide

hydrogen chloride

ethylenediaminetetraacetic acid

Superoxide dismutase

phosphate-buffered saline

2,4-dinitrophenyl hydrazine

sodium dodecyl sulphate-poly-acrylamide gel electrophoresis

bovine serum albumin

PBS with $0.1 \%$ Tween 20

glyceraldehyde-3-phosphate dehydrogenase

forkhead in rhabdomyosarcoma

Enhanced chemiluminescence

4',6-Diamidine-2'-phenylindole dihydrochloride

5'AMP-activated protein kinase

Sirtuin 1

peroxisome proliferator-activated receptor gamma coactivator 1- $\alpha$

protein kinase $B$

p70S6 kinase

beta-hydroxy-beta-methylglutaryl coenzyme A

phosphoinositide 3-kinase. 


\section{References}

1. Baker, B.A. Efficacy of Age-Specific High-Intensity Stretch-Shortening Contractions in Reversing Dynapenia, Sarcopenia, and Loss of Skeletal Muscle Quality. J. Funct. Morphol. Kinesiol. 2018, 3, 36. [CrossRef] [PubMed]

2. Morley, J.E.; Anker, S.D.; Von Haehling, S. Prevalence, incidence, and clinical impact of sarcopenia: Facts, numbers, and epidemiology-update 2014. J. Cachex-Sarcopenia Muscle 2014, 5, 253-259. [CrossRef] [PubMed]

3. Batsis, J.A.; A Mackenzie, T.; Barre, L.K.; Lopez-Jimenez, F.; Bartels, S.J. Sarcopenia, sarcopenic obesity and mortality in older adults: Results from the National Health and Nutrition Examination Survey III. Eur. J. Clin. Nutr. 2014, 68, 1001-1007. [CrossRef] [PubMed]

4. Cooper, R.; Kuh, D.; Hardy, R.; Mortality Review Group. FALCon and HALCyon Study Teams Objectively measured physical capability levels and mortality: Systematic review and meta-analysis. BMJ $2010,341$. [CrossRef]

5. Toth, M.J.; Ades, P.A.; Tischler, M.D.; Tracy, R.P.; LeWinter, M.M. Immune activation is associated with reduced skeletal muscle mass and physical function in chronic heart failure. Int. J. Cardiol. 2006, 109, $179-187$. [CrossRef] [PubMed]

6. Visser, M.; Pahor, M.; Taaffe, D.R.; Goodpaster, B.H.; Simonsick, E.M.; Newman, A.B.; Nevitt, M.; Harris, T.B. Relationship of Interleukin-6 and Tumor Necrosis Factor- With Muscle Mass and Muscle Strength in Elderly Men and Women: The Health ABC Study. J. Gerontol. Ser. A Boil. Sci. Med. Sci. 2002, 57. [CrossRef]

7. Schwartz, R.S.; Weindruch, R. Interventions Based on the Possibility That Oxidative Stress Contributes to Sarcopenia. J. Gerontol. Ser. A Boil. Sci. Med. Sci. 1995, 50, 157-161. [CrossRef]

8. Delsite, R.L.; Rasmussen, L.J.; Rasmussen, A.K.; Kalen, A.; Goswami, P.; Singh, K.K. Mitochondrial impairment is accompanied by impaired oxidative DNA repair in the nucleus. Mutagenesis 2003, 18, 497-503. [CrossRef]

9. Sullivan-Gunn, M.; Lewandowski, P. Elevated hydrogen peroxide and decreased catalase and glutathione peroxidase protection are associated with aging sarcopenia. BMC Geriatr. 2013, 13, 104. [CrossRef]

10. Marzetti, E.; Calvani, R.; Cesari, M.; Buford, T.W.; Lorenzi, M.; Behnke, B.J.; Leeuwenburgh, C. Mitochondrial dysfunction and sarcopenia of aging: from signaling pathways to clinical trials. Int. J. Biochem. Cell Boil. 2013, 45, 2288-2301. [CrossRef]

11. Busquets, S.; Alvarez, B.; Llovera, M.; Agell, N.; López-Soriano, F.J.; Argilés, J.M. Branched-chain amino acids inhibit proteolysis in rat skeletal muscle: mechanisms involved. J. Cell. Physiol. 2000, 184, 380-384. [CrossRef]

12. Glass, D.J. Signalling pathways that mediate skeletal muscle hypertrophy and atrophy. Nature 2003, 5, 87-90. [CrossRef] [PubMed]

13. Sandri, M.; Sandri, C.; Gilbert, A.; Skurk, C.; Calabria, E.; Picard, A.; Walsh, K.; Schiaffino, S.; Lecker, S.H.; Goldberg, A.L. Foxo Transcription Factors Induce the Atrophy-Related Ubiquitin Ligase Atrogin-1 and Cause Skeletal Muscle Atrophy. Cell 2004, 117, 399-412. [CrossRef]

14. Lecker, S.H.; Goldberg, A.L.; Mitch, W.E. Protein Degradation by the Ubiquitin-Proteasome Pathway in Normal and Disease States. J. Am. Soc. Nephrol. 2006, 17, 1807-1819. [CrossRef]

15. Bodine-Fowler, S. Identification of Ubiquitin Ligases Required for Skeletal Muscle Atrophy. Science 2001, 294, 1704-1708. [CrossRef]

16. Gomes, M.D.; Lecker, S.H.; Jagoe, R.T.; Navon, A.; Goldberg, A.L. Atrogin-1, a muscle-specific F-box protein highly expressed during muscle atrophy. Proc. Natl. Acad. Sci. USA 2001, 98, 14440-14445. [CrossRef]

17. Du, J.; Wang, X.; Miereles, C.; Bailey, J.L.; Debigare, R.; Zheng, B.; Price, S.R.; Mitch, W.E. Activation of caspase-3 is an initial step triggering accelerated muscle proteolysis in catabolic conditions. J. Clin. Invest. 2004, 113, 115-123. [CrossRef]

18. Eley, H.L.; Russell, S.T.; Tisdale, M.J. Mechanism of attenuation of muscle protein degradation induced by tumor necrosis factor-alpha and angiotensin II by beta-hydroxy-beta-methylbutyrate. Am. J. Physiol. Endocrinol. Metab. 2008, 295. [CrossRef]

19. Yakes, F.M.; Van Houten, B. Mitochondrial DNA damage is more extensive and persists longer than nuclear DNA damage in human cells following oxidative stress. Proc. Natl. Acad. Sci. USA 1997, 94, 514-519. [CrossRef] 
20. Calvani, R.; Joseph, A.-M.; Adhihetty, P.J.; Miccheli, A.; Bossola, M.; Leeuwenburgh, C.; Bernabei, R.; Marzetti, E. Mitochondrial pathways in sarcopenia of aging and disuse muscle atrophy. Boil. Chem. 2013, 394, 393-414. [CrossRef]

21. Tomassoni, D.; Amenta, F.; Amantini, C.; Farfariello, V.; Mannelli, L.D.C.; Nwankwo, E.; Marini, C.; Tayebati, S.K. Brain Activity of Thioctic Acid Enantiomers: In Vitro and in Vivo Studies in an Animal Model of Cerebrovascular Injury. Int. J. Mol. Sci. 2013, 14, 4580-4595. [CrossRef] [PubMed]

22. Bear, D.E.; Langan, A.; Dimidi, E.; Wandrag, L.; Harridge, S.D.R.; Hart, N.; Connolly, B.; Whelan, K. $\beta$-Hydroxy- $\beta$-methylbutyrate and its impact on skeletal muscle mass and physical function in clinical practice: A systematic review and meta-analysis. Am. J. Clin. Nutr. 2019, 109, 1119-1132. [CrossRef] [PubMed]

23. Molfino, A.; Gioia, G.; Fanelli, F.R.; Molfino, A. Beta-hydroxy-beta-methylbutyrate supplementation in health and disease: a systematic review of randomized trials. Amino Acids. 2013, 45, 1273-1292. [CrossRef] [PubMed]

24. Clark, R.H.; Feleke, G.; Din, M.; Yasmin, T.; Singh, G.; Khan, F.A.; Rathmacher, J.A. Nutritional treatment for acquired immunodeficiency virus-associated wasting using beta-hydroxy beta-methylbutyrate, glutamine, and arginine: A randomized, double-blind, placebo-controlled study. JPEN J. Parenter Enteral Nutr. 2000, 24, 133-139. [CrossRef]

25. Vukovich, M.D.; Stubbs, N.B.; Bohlken, R.M. Body composition in 70-year-old adults responds to dietary beta-hydroxy-beta-methylbutyrate similarly to that of young adults. J. Nutr. 2001, 131, 2049-2052. [CrossRef]

26. Eley, H.L.; Russell, S.T.; Baxter, J.H.; Mukerji, P.; Tisdale, M.J. Signaling pathways initiated by beta-hydroxy-beta-methylbutyrate to attenuate the depression of protein synthesis in skeletal muscle in response to cachectic stimuli. Am. J. Physiol. Endocrinol. Metab. 2007, 293, E923-E931. [CrossRef]

27. Smith, H.J. Mechanism of the Attenuation of Proteolysis-Inducing Factor Stimulated Protein Degradation in Muscle by -Hydroxy- -Methylbutyrate. Cancer Res. 2004, 64, 8731-8735. [CrossRef]

28. Wilson, G.J.; Wilson, J.M.; Manninen, A.H. Effects of beta-hydroxy-beta-methylbutyrate (HMB) on exercise performance and body composition across varying levels of age, sex, and training experience: A review. Nutr. Metab. 2008, 5, 1. [CrossRef]

29. Zanchi, N.; Gerlinger-Romero, F.; Guimarães-Ferreira, L.; Filho, M.A.D.S.; Felitti, V.; Lira, F.S.; Seelaender, M.C.L.; Lancha, A.H. HMB supplementation: Clinical and athletic performance-related effects and mechanisms of action. Amino Acids. 2010, 40, 1015-1025. [CrossRef]

30. Liu, J.; Head, E.; Gharib, A.M.; Yuan, W.; Ingersoll, R.T.; Hagen, T.M.; Cotman, C.W.; Ames, B.N. Memory loss in old rats is associated with brain mitochondrial decay and RNA/DNA oxidation: Partial reversal by feeding acetyl-L-carnitine and/or R- -lipoic acid. Proc. Natl. Acad. Sci. USA 2002, 99, 2356-2361. [CrossRef]

31. Palaniappan, A.R.; Dai, A. Mitochondrial Ageing and the Beneficial Role of $\alpha$-Lipoic Acid. Neurochem. Res. 2007, 32, 1552-1558. [CrossRef] [PubMed]

32. Liu, J. The Effects and Mechanisms of Mitochondrial Nutrient $\alpha$-Lipoic Acid on Improving Age-Associated Mitochondrial and Cognitive Dysfunction: An Overview. Neurochem. Res. 2007, 33, 194-203. [CrossRef] [PubMed]

33. Rousseau, A.-S.; Sibille, B.; Murdaca, J.; Mothe-Satney, I.; Grimaldi, P.A.; Neels, J. $\alpha$-Lipoic acid up-regulates expression of peroxisome proliferator-activated receptor $\mathrm{b}$ in skeletal muscle: Involvement of the JNK signaling pathway. Faseb J. 2015, 30, 1287-1299. [CrossRef] [PubMed]

34. Hong, O.; Son, J.W.; Kwon, H.-S.; Lee, S.-S.; Kim, S.R.; Yoo, S.J. Alpha-lipoic acid preserves skeletal muscle mass in type 2 diabetic OLETF rats. Nutr. Metab. 2018, 15, 66. [CrossRef]

35. Tomassoni, D. Morpho-functional Evaluation of the Activity of Stereoisomers of the Antioxidant Alpha-lipoic (Tioctic) Acid in a Model of Compressive Neuropathy. 2010, p. 166. Available online: https://www.torrossa. com/it/resources/an/2492010 (accessed on 30 April 2020). [CrossRef]

36. Kaasik, P.; Umnova, M.; Pehme, A.; Alev, K.; Aru, M.; Selart, A.; Seene, T. Ageing and dexamethasone associated sarcopenia: Peculiarities of regeneration. J. Steroid Biochem. Mol. Boil. 2007, 105, 85-90. [CrossRef]

37. Chiu, C.-S.; Weber, H.; Adamski, S.; Rauch, A.; A Gentile, M.; E Alves, S.; Kath, G.; Flores, O.; A Wilkinson, H. Non-invasive muscle contraction assay to study rodent models of sarcopenia. BMC Musculoskelet. Disord. 2011, 12, 246. [CrossRef]

38. Rieu, I.; Sornet, C.; Grizard, J.; Dardevet, M. Glucocorticoid excess induces a prolonged leucine resistance on muscle protein synthesis in old rats. Exp. Gerontol. 2004, 39, 1315-1321. [CrossRef] 
39. Shen, S.; Liao, Q.; Liu, J.; Pan, R.; Lee, S.M.-Y.; Lin, L.-G. Myricanol rescues dexamethasone-induced muscle dysfunction via a sirtuin 1-dependent mechanism. J. Cachex- Sarcopenia Muscle 2019, 10, 429-444. [CrossRef] [PubMed]

40. Lofberg, E.; Gutierrez, A.; Wernerman, J.; Anderstam, B.; Mitch, W.E.; Price, S.R.; Bergstrom, J.; Alvestrand, A. Effects of high doses of glucocorticoids on free amino acids, ribosomes and protein turnover in human muscle. Eur. J. Clin. Investig. 2002, 32, 345-353. [CrossRef]

41. Moghadam-Kia, S.; Werth, V.P. Prevention and treatment of systemic glucocorticoid side effects. Int. J. Dermatol. 2010, 49, 239-248. [CrossRef]

42. Chamberlain, J.S.; Rando, T.A. Dystrophin mutations predict cellular susceptibility to oxidative stress. Muscle Nerve. 2000, 23, 784-792. [CrossRef]

43. Lee, C.S.; Yi, J.-S.; Jung, S.-Y.; Kim, B.-W.; Lee, N.-R.; Choo, H.-J.; Jang, S.-Y.; Han, J.; Chi, S.-G.; Park, M.; et al. TRIM72 negatively regulates myogenesis via targeting insulin receptor substrate-1. Cell Death Differ. 2010, 17, 1254-1265. [CrossRef] [PubMed]

44. Auclair, D.; Garrel, D.R.; Zerouala, A.C.; Ferland, L.H. Activation of the ubiquitin pathway in rat skeletal muscle by catabolic doses of glucocorticoids. Am. J. Physiol. Physiol. 1997, 272. [CrossRef] [PubMed]

45. Czerwinski, S.M.; Wegrzyn, L.E.; Hickson, R.C. Glutamine Prevents Down-Regulation of Myosin Heavy Chain Synthesis and Muscle Atrophy from Glucocorticoids. Med. Sci. Sports Exerc. 1995, 27. [CrossRef]

46. Kayali, A.G.; Young, V.R.; Goodman, M.N. Sensitivity of myofibrillar proteins to glucocorticoid-induced muscle proteolysis. Am. J. Physiol. Metab. 1987, 252. [CrossRef]

47. Santidrian, S.; Moreyra, M.; Munro, H.N.; Young, V.R. Effect of corticosterone and its route of administration on muscle protein breakdown, measured in vivo by urinary excretion of $\mathrm{N}$ tau-methylhistidine in rats: response to different levels of dietary protein and energy. Metabolism 1981, 30, 798-804. [CrossRef]

48. Thompson, M.G.; Thom, A.; Partridge, K.; Garden, K.; Campbell, G.P.; Calder, G.; Palmer, R.M. Stimulation of myofibrillar protein degradation and expression of mRNA encoding the ubiquitin-proteasome system in C(2)C(12) myotubes by dexamethasone: effect of the proteasome inhibitor MG-132. J. Cell. Physiol. 1999, 181, 455-461. [CrossRef]

49. Stitt, T.N.; Drujan, D.; Clarke, B.A.; Panaro, F.; Timofeyva, Y.; Kline, W.O.; Gonzalez, M.; Yancopoulos, G.D.; Glass, D.J. The IGF-1/PI3K/Akt pathway prevents expression of muscle atrophy-induced ubiquitin ligases by inhibiting FOXO transcription factors. Mol. Cell. 2004, 14, 395-403. [CrossRef]

50. Menconi, M.; Gonnella, P.; Petkova, V.; Lecker, S.; Hasselgren, P.-O. Dexamethasone and corticosterone induce similar, but not identical, muscle wasting responses in cultured L6 and C2C12 myotubes. J. Cell. Biochem. 2008, 105. [CrossRef]

51. Gueugneau, M.; D’Hose, D.; Barbé, C.; De Barsy, M.; Lause, P.; Maiter, D.; Bindels, L.B.; Delzenne, N.M.; Schaeffer, L.; Gangloff, Y.-G.; et al. Increased Serpina3n release into circulation during glucocorticoid-mediated muscle atrophy. J. Cachex- Sarcopenia Muscle 2018, 9, 929-946. [CrossRef]

52. Marinovic, A.C.; Zheng, B.; Mitch, W.E.; Price, S.R. Tissue-specific regulation of ubiquitin (UbC) transcription by glucocorticoids: in vivo and in vitro analyses. Am. J. Physiol. Physiol. 2007, 292. [CrossRef] [PubMed]

53. Porporato, P.E.; Filigheddu, N.; Reano, S.; Ferrara, M.; Angelino, E.; Gnocchi, V.F.; Prodam, F.; Ronchi, G.; Fagoonee, S.; Fornaro, M.; et al. Acylated and unacylated ghrelin impair skeletal muscle atrophy in mice. J. Clin. Investig. 2013, 123. [CrossRef] [PubMed]

54. Shimizu, N.; Yoshikawa, N.; Ito, N.; Maruyama, T.; Suzuki, Y.; Takeda, S.-I.; Nakae, J.; Tagata, Y.; Nishitani, S.; Takehana, K.; et al. Crosstalk between Glucocorticoid Receptor and Nutritional Sensor mTOR in Skeletal Muscle. Cell Metab. 2011, 13, 170-182. [CrossRef] [PubMed]

55. Hasty, P.; Bradley, A.; Morris, J.H.; Edmondson, D.G.; Venuti, J.M.; Olson, E.N.; Klein, W.H. Muscle deficiency and neonatal death in mice with a targeted mutation in the myogenin gene. Nature 1993, 364, 501-506. [CrossRef] [PubMed]

56. Perry, R.L. Molecular mechanisms regulating myogenic determination and differentiation. Front. Biosci. 2000, 5. [CrossRef]

57. Langley, B.; Thomas, M.; Bishop, A.; Sharma, M.; Gilmour, S.; Kambadur, R. Myostatin Inhibits Myoblast Differentiation by Down-regulating MyoD Expression. J. Boil. Chem. 2002, 277, 49831-49840. [CrossRef]

58. Pas, M.F.T.; De Jong, P.R.; Verburg, F.J. Glucocorticoid inhibition of C2C12 proliferation rate and differentiation capacity in relation to mRNA levels of the MRF gene family. Mol. Boil. Rep. 2000, 27, 87-98. [CrossRef] 
59. Oshima, Y.; Kuroda, Y.; Kunishige, M.; Matsumoto, T.; Mitsui, T. Oxidative stress-associated mitochondrial dysfunction in corticosteroid-treated muscle cells. Muscle Nerve 2004, 30, 49-54. [CrossRef]

60. Mitsui, T.; Azuma, H.; Nagasawa, M.; Iuchi, T.; Akaike, M.; Odomi, M.; Matsumoto, T. Chronic corticosteroid administration causes mitochondrial dysfunction in skeletal muscle. J. Neurol. 2002, 249, 1004-1009. [CrossRef]

61. Winiarska, K.; Malińska, D.; Szymanski, K.; Dudziak, M.; Bryla, J. Lipoic acid ameliorates oxidative stress and renal injury in alloxan diabetic rabbits. Biochimie 2008, 90, 450-459. [CrossRef]

62. Muller, F.; Song, W.; Liu, Y.; Chaudhuri, A.; Pieke-Dahl, S.; Strong, R.; Huang, T.-T.; Epstein, C.J.; Roberts, L.J.; Csete, M.; et al. Absence of CuZn superoxide dismutase leads to elevated oxidative stress and acceleration of age-dependent skeletal muscle atrophy. Free. Radic. Boil. Med. 2006, 40, 1993-2004. [CrossRef] [PubMed]

63. Choi, M.H.; Ow, J.R.; Yang, N.-D.; Taneja, R. Oxidative Stress-Mediated Skeletal Muscle Degeneration: Molecules, Mechanisms, and Therapies. Oxidative Med. Cell. Longev. 2016, 2016, 1-13. [CrossRef] [PubMed]

64. Bilska, A.; Włodek, L. Lipoic acid-the drug of the future? Pharmacol. Rep. 2005, 57, 570-577.

65. Matsugo, S.; Yan, L.-J.; Han, D.; Trischler, H.; Packer, L. Elucidation of Antioxidant Activity of $\alpha$-Lipoic Acid Toward Hydroxyl Radical. Biochem. Biophys. Res. Commun. 1995, 208, 161-167. [CrossRef] [PubMed]

66. Borcea, V.; Nourooz-Zadeh, J.; Wolff, S.P.; Klevesath, M.; Hofmann, M.; Urich, H.; Wahl, P.; Ziegler, R.; Tritschler, H.; Halliwell, B.; et al. $\alpha$-lipoic acid decreases oxidative stress even in diabetic patients with poor glycemic control and albuminuria. Free. Radic. Boil. Med. 1999, 26, 1495-1500. [CrossRef]

67. Tibullo, D.; Volti, G.L.L.; Giallongo, C.; Grasso, S.; Tomassoni, D.; Anfuso, C.D.; Lupo, G.; Amenta, F.; Avola, R.; Bramanti, V. Biochemical and clinical relevance of alpha lipoic acid: antioxidant and anti-inflammatory activity, molecular pathways and therapeutic potential. Inflamm. Res. 2017, 66, 947-959. [CrossRef] [PubMed]

68. Gomes, M.B.; Negrato, C.A. Alpha-lipoic acid as a pleiotropic compound with potential therapeutic use in diabetes and other chronic diseases. Diabetol. Metab. Syndr. 2014, 6, 80. [CrossRef]

69. Jurisic-Erzen, D.; Starcevic-Klasan, G.; Ivanac, D.; Peharec, S.; Girotto, D.; Jerkovic, R. The effects of alpha-lipoic acid on diabetic myopathy. J. Endocrinol. Investig. 2017, 41, 203-209. [CrossRef]

70. Mohammed, M.A.; Mahmoud, M.O.; Awaad, A.S.; Gamal, G.M.; Abdelfatah, D. Alpha lipoic acid protects against dexamethasone-induced metabolic abnormalities via APPL1 and PGC-1 $\alpha$ up regulation. Steroids 2019, 144, 1-7. [CrossRef]

71. Kaczka, P.; Michalczyk, M.M.; Jastrzab, R.; Gawelczyk, M.; Kubicka, K. Mechanism of Action and the Effect of Beta-Hydroxy-Beta-Methylbutyrate (HMB) Supplementation on Different Types of Physical Performance-Systematic Review. J. Hum. Kinet. 2019, 68, 211-222. [CrossRef]

72. Russell, S.T.; Tisdale, M.J. Mechanism of attenuation by beta-hydroxy-beta-methylbutyrate of muscle protein degradation induced by lipopolysaccharide. Mol. Cell. Biochem. 2009, 330, 171-179. [CrossRef] [PubMed]

73. Standley, R.A.; Distefano, G.; Pereira, S.L.; Tian, M.; Kelly, O.; Coen, P.M.; Deutz, N.E.P.; Wolfe, R.R.; Goodpaster, B.H. Effects of $\beta$-hydroxy- $\beta$-methylbutyrate on skeletal muscle mitochondrial content and dynamics, and lipids after 10 days of bed rest in older adults. J. Appl. Physiol. 2017, 123, 1092-1100. [CrossRef] [PubMed]

74. Wilson, J.M.; Lowery, R.P.; Joy, J.M.; Walters, J.A.; Baier, S.M.; Fuller, J.C.; Stout, J.R.; Norton, L.E.; Sikorski, E.M.; Wilson, S.M.C.; et al. $\beta$-Hydroxy- $\beta$-methylbutyrate free acid reduces markers of exercise-induced muscle damage and improves recovery in resistance-trained men. Br. J. Nutr. 2013, 110, 538-544. [CrossRef] [PubMed]

75. Cruz-Jentoft, A.J. Beta-Hydroxy-Beta-Methyl Butyrate (HMB): From Experimental Data to Clinical Evidence in Sarcopenia. Curr. Protein Pept. Sci. 2018, 19, 668-672. [CrossRef]

76. Kornasio, R.; Riederer, I.; Butler-Browne, G.; Mouly, V.; Uni, Z.; Halevy, O. Beta-hydroxy-beta-methylbutyrate (HMB) stimulates myogenic cell proliferation, differentiation and survival via the MAPK/ERK and PI3K/Akt pathways. Biochim. Biophys. Acta 2009, 1793, 755-763. [CrossRef]

77. Baptista, I.L.; Silva, W.J.; Artioli, G.G.; Guilherme, J.P.L.F.; Leal, M.L.; Aoki, M.S.; Miyabara, E.H.; Moriscot, A.S. Leucine and HMB differentially modulate proteasome system in skeletal muscle under different sarcopenic conditions. PLoS ONE 2013, 8, 76752. [CrossRef]

(C) 2020 by the authors. Licensee MDPI, Basel, Switzerland. This article is an open access article distributed under the terms and conditions of the Creative Commons Attribution (CC BY) license (http://creativecommons.org/licenses/by/4.0/). 